\title{
EFFECT OF POTENTIAL ALLELOPATHIC EGYPTIAN RICE CULTIVARS AGAINST Echinochloa crus-galli AND Echinochloa colonum \\ Ashry, M.A. ${ }^{1}$; A. A. Zein ${ }^{1}$; M. F. El - Nady ${ }^{2}$ and Sh. M. Abdel-Dayem 1 \\ ${ }^{1}$ Dept. of Pesticides, ${ }^{2}$ Dept. of Agric. Botany, Fac. of Agric., Kafrelsheikh Univ., Egypt
}

\begin{abstract}
With the burgeoning population of the world, achieving the food security has become a challenge to mankind; as a result only yield maximization is becoming the last word of modern agriculture. Although this approach is satisfying the food demand to almost a desirable extent, but is directly and indirectly causing negative impact on quality of the product, environment and overall human health. This system is mostly based on the use of heavy doses of herbicides to control weeds. Therefore, these experiments were conducted in order to investigate a quick seedling test for allelopathic potential of rice cultivars [Egyptian Jasmine (E. Jasmine) and sakha 104] and allelopathic potential of methanol extract of rice cultivars seedlings and as sown rice cultivars on seed germination \%, growth and anatomical parameters of the two tested rice weeds (Echinochloa crus-galli and Echinochloa colonum). The obtained results indicated that, reduction in seed germination \%, growth parameters of the two tested rice weeds were recorded by methanol extract of allelopathic rice cultivar $(E$. Jasmine) and as sown with rice cultivars application. Anatomical changes were obtained in the both rice weeds treated with methanol extract of rice cultivar $(\mathrm{E}$. Jasmine). This may led to avoid or at least reduce the frequent use of herbicides in rice crop production sector. These results suggest that rice plant methanol extract may be a source of natural herbicide (bioherbicide).

Keywords : Bioherbicides allelopathy, percent of germination, fresh and dry weight,
\end{abstract} anatomical differences, morphological parameters.

\section{INTRODUCTION}

Improvement in rice cultivars is an area that could be developed as a weed management strategy, and thus the development of weed-suppressing rice development of a commercially acceptable allelopathic cultivar have not been obtained so far (Kong et al. 2008). Few studies have clearly shown that the use of allelopathic rice cultivars can definitely reduce the cost of paddy weed control, particularly by reducing the amount of herbicides used. (Olofsdotter et al. 2002; Gealy et al. 2003 and Duke. 2007). Such an allelopathy based technique for paddy weed control is most easily transferable to the low-input management systems prevailing throughout most rice-farming systems.( Shibayama 2001 and Minorsky 2002 ). Actually, a number of techniques have been evaluated as alternatives to synthetic herbicides in weed management systems, including cultural management, allelopathy and bioherbicides. However, significant developments in weed management for low input agriculture will require the careful integration of these multiple techniques.( Liebman and Davis 2000 and Charudattan 2001) . Rice allelopathy might prove useful in controlling paddy weeds and increasing grain yields, but paddy weed control by using an allelopathic rice variety 
Ashry, M.A. et al.

alone may not be adequate. Therefore, several management options will need to be combined with the suppressive effect of the allelopathic rice variety to facilitate effective weed control at reduced herbicide rates. In this study, the weed-suppressive effects of allelopathic rice cultivar (E. Jasmine) and a non-allelopathic rice cultivar (Sakha 104) were evaluated under several cultural management options to develop an allelopathy based technique to reduce herbicide use in paddy weed control.

\section{MATERILAS AND METHODS}

A quick seedling test for Allelopathic potential of rice cultivars.

Rice cultivars: Egyptian Jasmine (E. Jasmine) and sakha 104 were used in this study. Seeds of those cultivars were supplied from Rice Research and Training Center (RRTC) Sakha, Kafer El-Sheikh, Egypt.. On the other hand two weed species, i.e. Echinochloa crus-galli and Echinochloa colonum were used for bioassay. Those two weeds are the two major weeds in rice fields. Seeds of both tested rice cultivars and tested weed species were sown in Petri -dishes on a cotton layer.

Tested Parameters:

1- Percent of inhibition of weed species germination after 10 days from sowing was determined by the following equation:

$$
I(\%)=\frac{A}{B} \times 100
$$

Where:

$1 \%=$ Percent of inhibition of weed germination .

$\mathrm{A}=$ number of emergence weed seeds sowing with rice cultivars

$\mathrm{B}=$ number of emergence weed seeds sowing without rice cultivars

2- Plant height $(\mathrm{cm})$ :

Five weed plants randomly selected from each Petri-dish were height measured, their average of height was recorded.

3- Plant fresh weight was determined by randomly taking five weed plants from each Petri-dish, weighted and the average of fresh weight was recorded. 4- Plant dry weight was determined by randomly taking of five weed plants from each Petri-dish, dried for two days in an oven at $700 \mathrm{C}$ till fixed weight. The average of dry weight was recorded

\section{Incubation of rice and extraction}

Rice seeds were sown in plastic pots $(30 \times 30 \times 30 \mathrm{~cm})$, each contained $7 \mathrm{Kg}$ of soil. The seedlings were allowed to grow for 15 days. Rice seedlings were harvested and $40 \mathrm{~g}$ (fresh weight) of them were homogenized with $80 \%$ aqueous methanol (200 ml.). After homogenization the extract was filtered through one layer of filter paper (Whatman Cat No 101). The residues were again homogenized with methanol and filtered through the filter paper. The two filtrates were combined and the methanol was evaporated with a rotary evaporator at $40^{\circ} \mathrm{C}$.

Bioassay:

As the final assay concentration was 0.00 for control treatment and $0.02,0.06,0.20$ or $0.60 \mathrm{~g}$ fresh weight rice plant equivalent extract $\mathrm{ml}^{-1}$ for 
treatments, an aliquot of the extract was evaporated to dryness, dissolved in $0.5 \mathrm{ml}$. of methanol and added to a sheet of filter paper (Whatman Cat No 101) in a $9 \mathrm{~cm}$ Petri- dish. Methanol was evaporated and ten seeds of each weed were sown in Petri dishes. After 10 days of incubation in greenhouse at $25^{\circ} \mathrm{C}$, the length of their shoots and roots was measured. Inhibition percentage $(1 \%)$ of hypocotyls /shoot and root was determined by the following equation:

$$
1 \%=\frac{C-D}{C} \times 100
$$

Where:

I $\%=$ inhibition percent of hypocotyls / shoot and root.

$\mathrm{C}=$ control length.

$\mathrm{D}$ = length after incubation of rice seedlings in methanol extract.

Light microscopic analysis:

Root specimens were taken on the $10^{\text {th }}$ day of treating with higher concentration $(0.6 \mathrm{gm} . / \mathrm{ml}$.) of the methanol extract of the allelopathic rice cultivar E. Jasmine. Specimens were fixed in $0.5 \%$ buffered glutaraldehyde in $0.1 \mathrm{M}$ PBS (phosphate-buffer-saline), $\mathrm{pH} 7.4$ at $40 \mathrm{C}$ for $2 \mathrm{~h}$. Specimens were washed three times with PBS (10 min. each) and post fixation in 1\% osmic acid for (30min). Then dehydrated with ascending series of ethyl alcohol (30, $50,70,90 \%$ and absolute alcohol) each concentration for $30 \mathrm{~min}$. Infiltrated with acetone for 1 hour. In Transmutation Electron microscope (TEM), after dehydration samples were embedded in Araldite 502 resin. The plastic molds were cut in the LEICA Ultracut UCT ultra-microtome, stained with $1 \%$ toleudine blue. Ten reading from 3 slides were examined with electric microscope (Lieca DM LS) with digital camera (Lieca DC 300), then photographed. The histological manifestation were calculated using Lieca IM 1000 image manager software. Lieca software was calibrated using $1 \mathrm{~cm}$ stage micrometer scaled at $100 \mu \mathrm{m}$ increment (Leitz Wetzler, Germany $604364)$ at 4 and $10 X$ magnifications.

\section{RESULTS AND DISCUSSION}

\section{A quick seedling test for Allelopathic potential of rice cultivar.}

When diferent plants grow together they compete with each other physically and chemically. Traditionally, such competition had been divided into plant competition and allelopathy. Competition had been defined as sharing the same limited growing resources, such as space, light, water and nutrients, whereas allelopathy is understood as the e.ect of chemical interactions between plants. As a rule of thumb, one can say, that competition is the removal of shared resources whereas allelopathy is addition of chemicals to the environment. Phytotoxic compounds are released from the plant roots. Rice is an example, where living rice plants are able to suppress weed growth selectively (Fujii 1992, Navarez and Olofsdotter 1996, Olofsdotter et al. 1997). When testing different varieties, allelopathy and resource competition cannot be separated under field conditions and 
Ashry, M.A. et al.

therefore selection under field conditions is not an option. Therefore, a laboratory screening system which is reliable, fast, cheap and space-limited has to be used. Various laboratory screening techniques have been developed to demonstrate, measure and quantify allelopathy without the interference of resource competition (Leather and Einhellig 1986, Fujii 1992, Navarez and Olofsdotter 1996, Kawaguchi et al. 1997).

Effect of non - allelopathic rice cultivar (Sakha 104) and allelopathic rice cultivar (Egyptian Jasmine) on seed germination of Echinochloa crusgalli and Echinochloa. colonum.

Germination tests have been used to demonstrate allelopathic potential, Fig. (1). Allelopathic rice cultivar (E. Jasmine) are capable of reducing seed germination of Echinochloa crus-galli and Echinochloa colonum substantially using the screening technique described. Apart from reducing germination, (Fig 1) show that allelopathic (c.v. E. Jasmine) seemed to inhibit seed germination of Echinochloa crus-galli and Echinochloa colonum when these two weeds were grown with non-allelopathic rice (c.v. Sakha 104). Seed germination \% of E. crus-galli and E. colonum seedlings grown together with (E. Jasmine) were significantly less than those grown together with Sakha 104. E. Jasmine cultivar inhibited the seed germination of E.crus-galli and E. colonum to 34.46 and 38.88 . \% of the control, respectively.

Our results are in agreement with results of Chung et al. (2002) and Heidarzade, et al., (2010) who suggested that Ferulic, p-hydroxybenzoic, vanillic, $\mathrm{p}$-coumaric, and $\mathrm{m}$-coumaric acids were the most active compounds and caused the greatest inhibitory effect on seed germination \% of barnyardgrass (Echinochloa crus-galli). Mattice et al. (1998), suggested that allelopathy of rice against weeds is correlated with the amounts of phenolic acids released by living rice roots. Rice can release many kinds of secondary metabolites through its root tissues. These metabolites in rice exudates possess multiple functions on the chemical interactions among organisms in the environment (Bacilio et al., 2003), and allelopathy is one of multiple functions among metabolites (Kato-Noguchi and Ino., 2005), also, to exert phytotoxic effects on other plant species, chemicals may have to move to the roots of the target plant (Inderjit, 2006). Allelopathy refers to plant-plant interference mediated mostly by plant released products of secondary metabolism. It was recently suggested that allelochamicals may influence growth of neighboring plants by induction of oxidative stress. Plant growth and development as well as plant response to stresses is controlled also by phytohormones. Ethylene and abscisic acid (ABA) are both regarded as typical stress hormones; they are also involved in regulation of seed dormancy and germination (Kucera, et al., 2005). The disturbances in phytohormone levels leads to decreasing metabolic activity of the embryo and blocking its germination (Bogatek, and Gniazdowska (2007). 


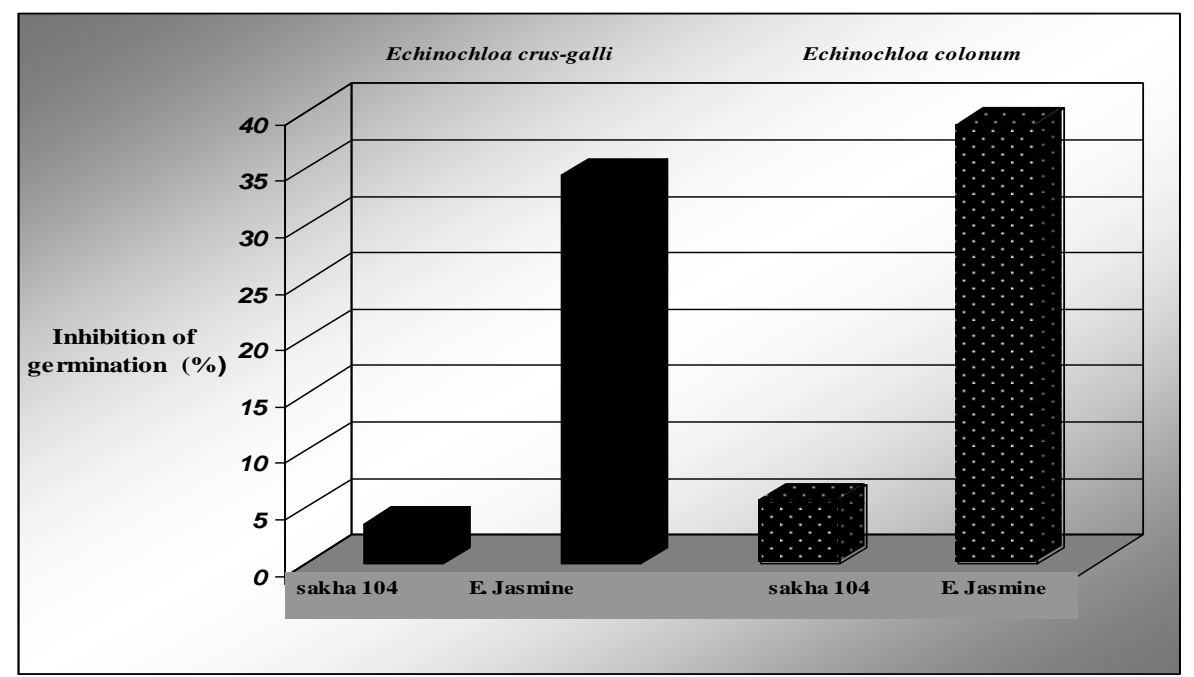

Fig. (1): Effect of non - allelopathic rice cultivar (Sakha 104) and allelopathic rice cultivar (Egyptian Jasmine) on seed germination of Echinochloa crus-galli and Echinochloa colonum.

Effect of non - allelopathic rice cultivar (Sakha 104) and allelopathic rice cultivar (Egyptian Jasmine) on the shoots and roots length of Echinochloa crus-galli and Echinochloa. colonum.

Figs (2 and 3 ) shows the allelopathic potential of the tested two rice cultivars as determined against the length of shoots and roots of E. crus-galli and $E$. colonum. These two rice cultivars, on average, inhibited the shoot length of E. crus-galli and E. colonum to 50.09011 and 57.13 . \% of the control, respectively, Also the root length of E. crus-galli and E. colonum to 67.15 and $82.37 \%$ of the control when grown with (E. Jasmine), respectively. The effects of the tested two rice cultivars, on the test plant species and their interactions were significant both for shoot and root length. Significant effects of the cultivar and the interactions indicated that there was variation in allelopathic activity among the two rice cultivars. This variation might be a result, in part, of the difference in sensitivity to allelochemicals of the test plant species.

Moreover, this therefore related to the inhibition of cell expansions as well as reduced rates of new cell production effect may be attributed to the results of massive and irreversible expansion of small daughter cells produced by meristematic divisions and growth inhibition may make additional contribution to the inhibition of growth. Moreover, this effect may be attributed to losses in tissue water content, which reduce turgor pressure in the cell, thereby inhibiting enlargement and division of cells causing a reduction in plant growth. In last few years numerous articles relating to allelopathy interactions were published, although data on mechanism of action of identified allelochemicals are still exceptional [Bais,, et al., (2003) and Weir, et al., (2004)]. 
Ashry, M.A. et al.

It was also found that rice cultivars which were allelopathic against one plant species were not always allelopathic towards other plant species (Dilday et al., 1994; Olofsdotter et al., 1995; Chung et al.,1997; Dilday et al., 1998; Hassan et al., 1998). It was suggests that all allelochemicals released from rice plants may not be able to inhibit all plant species. In the present experiment, however, (E. Jasmine) marked the greatest inhibitory activity .This inhibition by (E. Jasmine) was greater in the roots than the shoots for all test plant species. This may be due to the ridicule is the first organ to come directly contact with allelochemical substances in the soil. In spite of the heavy use of commercial herbicides to control weeds, crop yield loss from weed remains high (Putnam 1988; Weston 1996; Einhellig 1996). The negative impacts of commercial herbicides used on the environmental contamination make it necessary to diversify weed management options. Controlling weeds through allelopathy is one strategy to reduce commercial herbicide dependency (Putnam 1988; Duke et al. 2000). The present study suggests that rice cultivar (E. Jasmine) is the most allelopathic of the two tested rice cultivars. This cultivar, therefore, may be one of the candidates for research rice allelopathy for isolation and identification of allelochemicals.

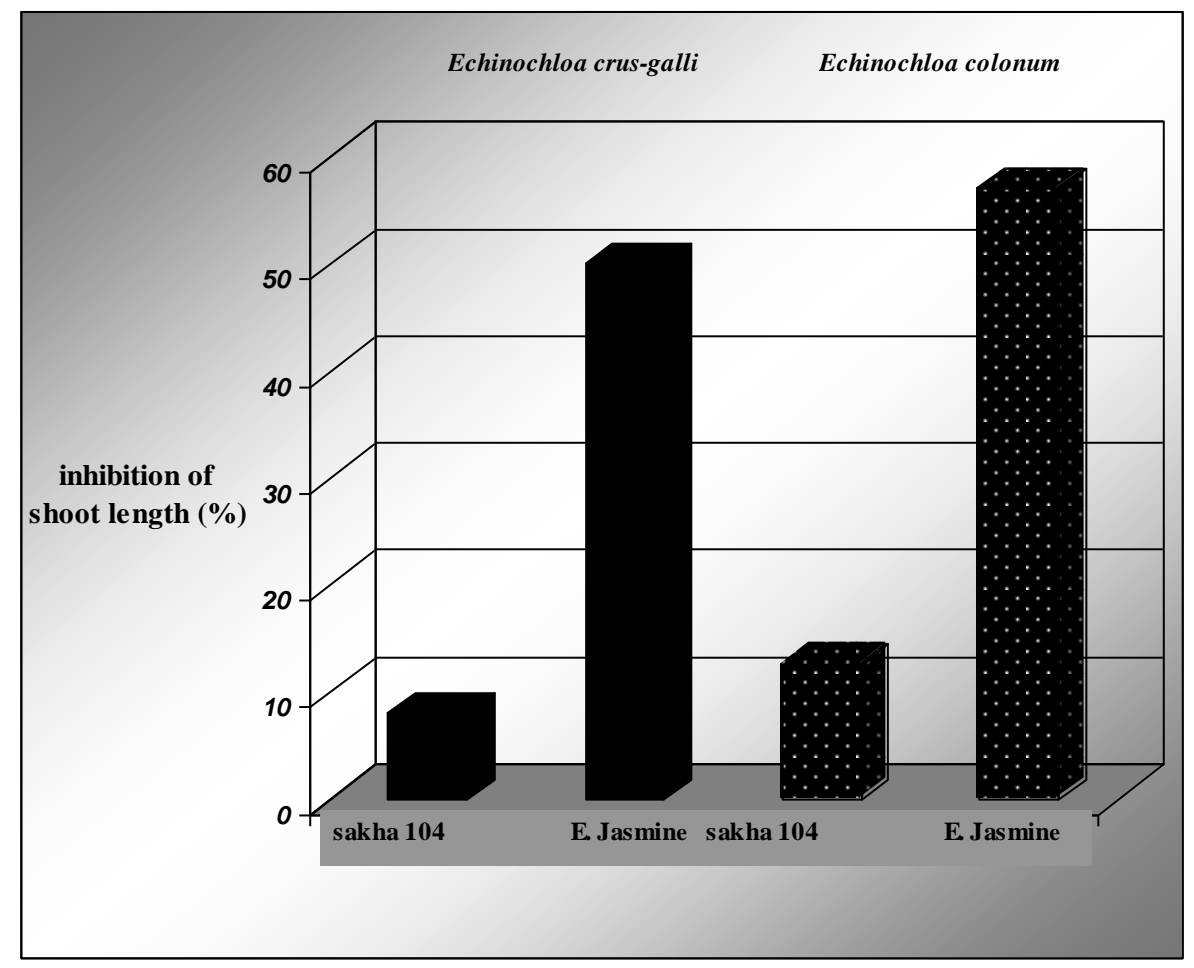

Fig. (2): Effect of non - allelopathic rice cultivar (Sakha 104) and allelopathic rice cultivar (Egyptian Jasmine) on the shoot length of Echinochloa crus-galli and Echinochloa. colonum. 


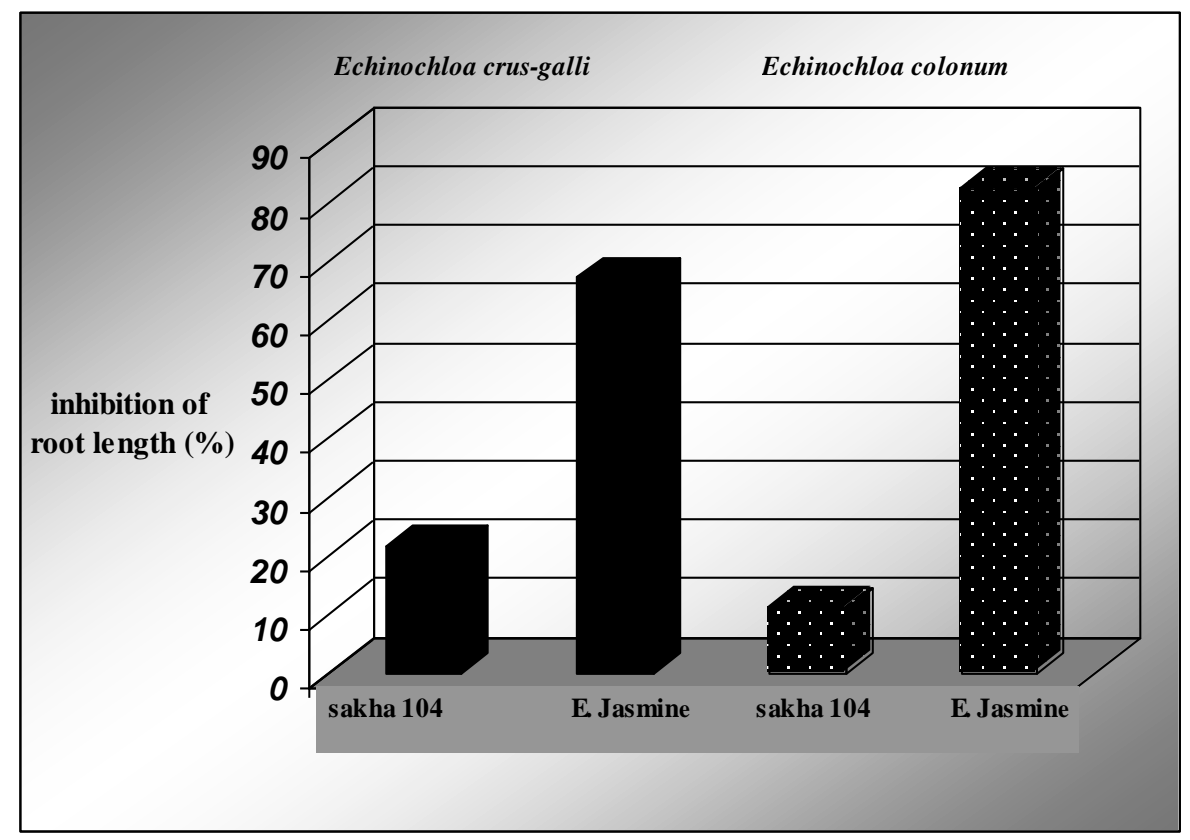

Fig. (3): Effect of non - allelopathic rice cultivar (Sakha 104) and allelopathic rice cultivar (Egyptian Jasmine) on the root length of Echinochloa crus-galli and Echinochloa. colonum.

Effects of non - allelopathic rice cultivar (Sakha 104) and allelopathic rice cultivar (Egyptian Jasmine) on the plant fresh and dry weight of Echinochloa crus-galli and Echinochloa colonum.

Figs (4 and 5) indicated that allelopathic potential of rice cultivars (E. Jasmine) and Sakha 104 were determined against the plant fresh and dry weight of E. crus-galli and E. colonum. These two rice cultivars, on average, inhibited the plant fresh weight of both tested weeds to 80.75 and 78.43 . \% as compared with control, respectively, On the other hand the plant dry weight of E. crus-galli and E. colonum was inhibited by 75.70 and $85.07 \%$ of the control, respectively when they were grown with (E. Jasmine). The effect of Sakha 104 might be due to the competition to the weeds, while the effects of (E. Jasmine) were refereed to allelopathy. The reduction in fresh weight may be attributed to losses in tissue water content, which reduce turgor pressure in the cell, thereby inhibiting enlargement and division of cells causing a reduction in plant growth (plant height). Moreover, reduction in plant water content may be due to the reduction in water absorption and nutrient uptake. 
Ashry, M.A. et al.

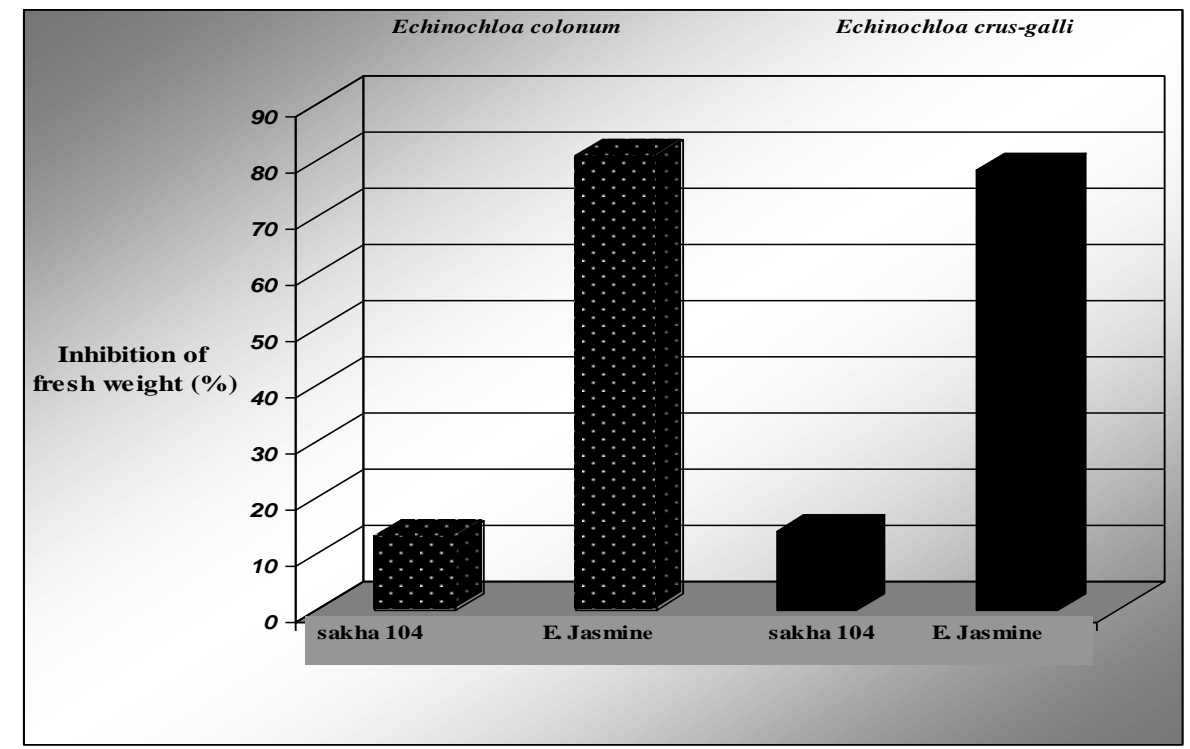

Fig. (4): Effects of non - allelopathic rice cultivar (Sakha 104) and allelopathic rice cultivar (Egyptian Jasmine) on the fresh weight of Echinochloa crus-galli and Echinochloa colonum.

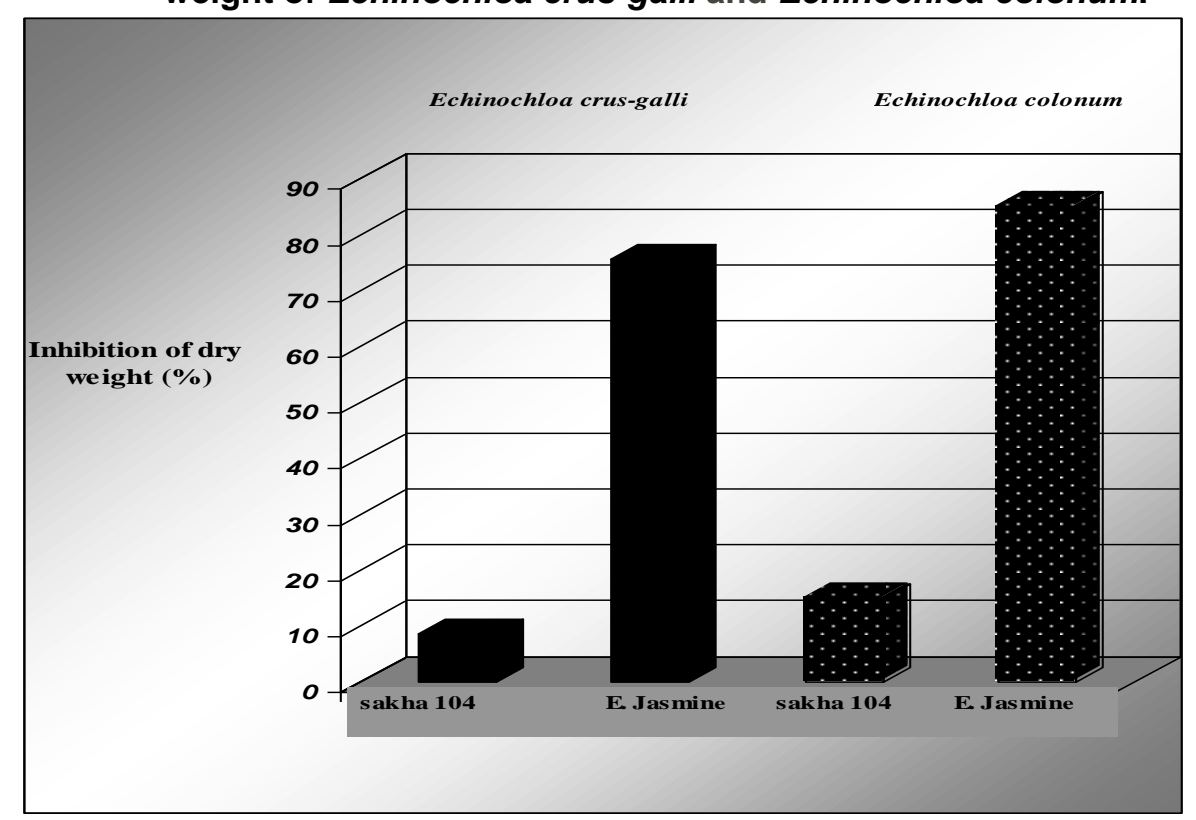

Fig. (5): Effects of non - allelopathic rice cultivar (Sakha 104) and allelopathic rice cultivar (Egyptian Jasmine) on the dry weight of Echinochloa crus-galli and Echinochloa. colonum. 
Effects of methanol extract of rice seedlings (c.v. E.Jasmine) on the shoots and roots growth of Echinochloa crus-galli seedlings

Fig (6) shows the effects of methanol extracts of rice cultivar (E.Jasmine) on shoot length of Echinochloa crus-galli. It was found that the inhibitory effect was increased with increasing concentrations of methanol extract. The highest inhibitory effect $(88.7 \%$ and $88.11 \%)$ was obtained by the extract at concentration of $0.6 \mathrm{~g} / \mathrm{ml}$ on Echinochloa crus-galli in 2010 and 2011 seasons, respectively.

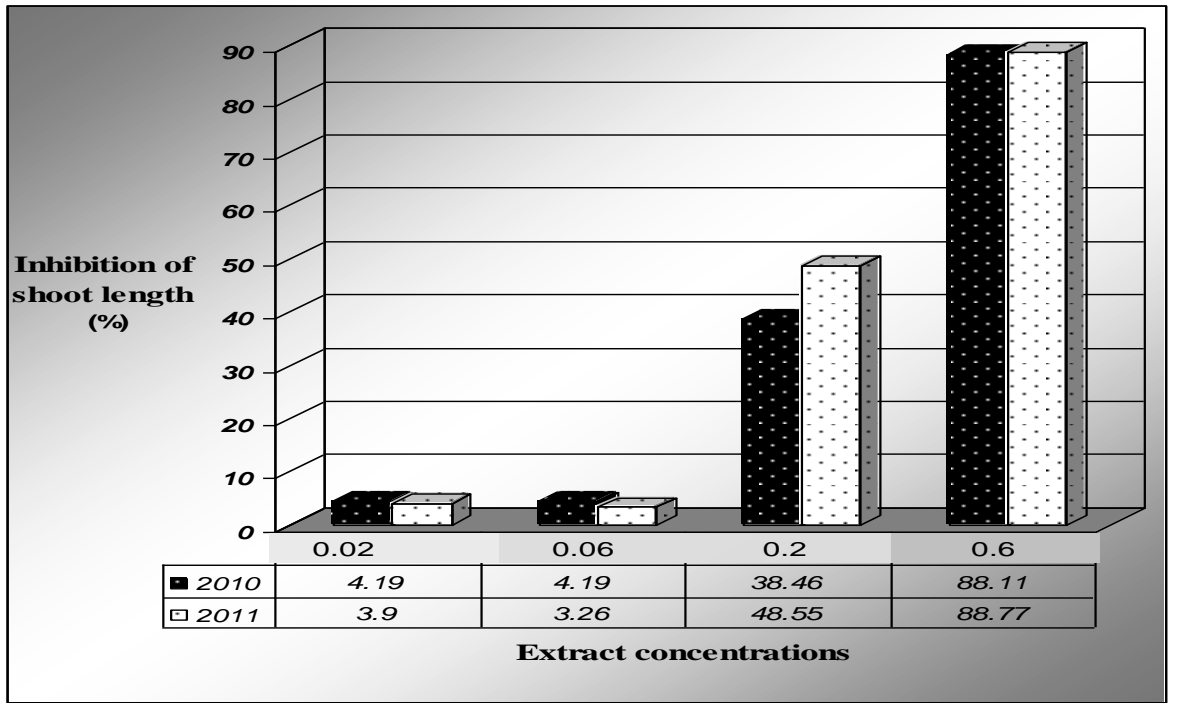

Fig. 6: Effects of methanol extracts of rice seedlings (c.v. E.Jasmine) on shoot length of Echinochloa crus-galli seedlings as treated by Concentrations of tested samples corresponded to the extract obtained from 0.00 (control), $0.02,0.06,0.2$ and $0.6 \mathrm{~g}$ fresh weight of rice plants $\mathrm{ml}^{-1}$.

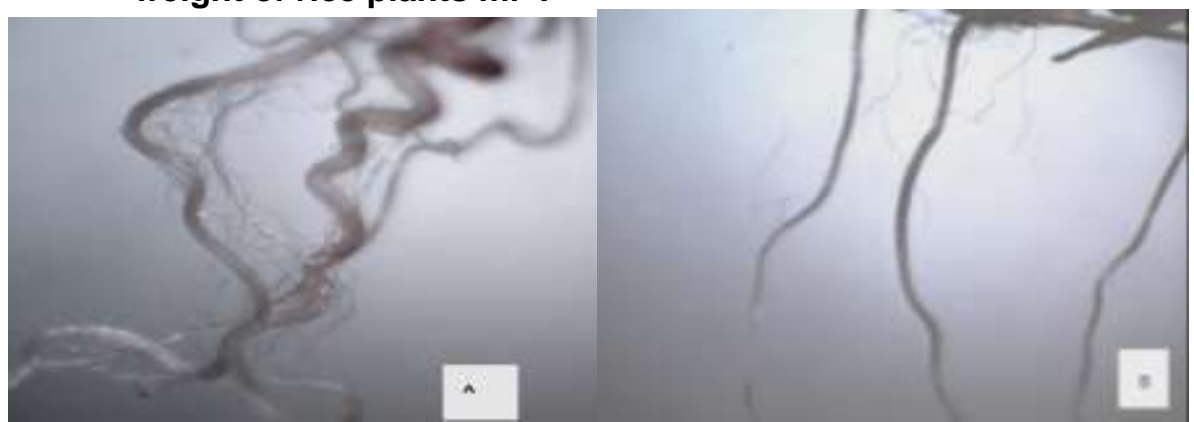

Fig. 7: Photomicrographs of Echinochloa crus-galli roots treated with methanol extract of rice seedlings (c.v. E.Jasmine) resulted from the concentration of 0.00 (control), and $0.6 \mathrm{gm}$ fresh weight of rice plants $/ \mathrm{ml}$. A: 0.00 (control) B: treated with methanol extract of rice seedlings (c.v. E.Jasmine) at $0.6 \mathrm{gm}$ fresh weight of rice plants $/ \mathrm{ml}$. 
Ashry, M.A. et al.

Fig (8) Effects of methanol extract of rice cultivar (c.v. E.Jasmine) on root length of Echinochloa crus-galli. At concentration of $0.6 \mathrm{gm} / \mathrm{ml}$, the highest root length inhibition was 88.7 in season 2010 and $90.8 \%$ in season 2011

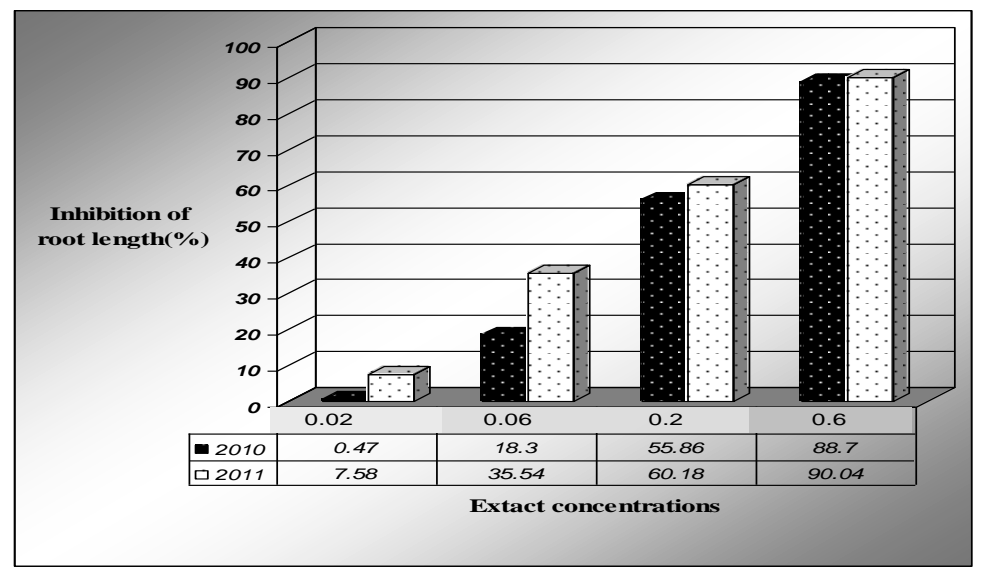

Fig. 8: Effects of methanol extracts of rice seedlings (c.v. E.Jasmine) on root length of Echinochloa crus-galli seedlings as treated by Concentrations of tested samples corresponded to the extract obtained from 0.00 (control), $0.02,0.06,0.2$ and $0.6 \mathrm{~g}$ fresh weight of rice plants $\mathrm{ml}^{-1}$.

Effects of methanol extract of rice seedlings (c.v. E.Jasmine) on the shoots and roots growth of Echinochloa colonum seedlings.

Figs 9 and 10 shows the effects of methanol extracts of rice cultivar (c.v. E.Jasmine) on shoot and root growth of Echinochloa colonum. Figs 9 indicated that the concentration $0.2 \mathrm{gm} / \mathrm{ml}$, showed the inhibitory effect as $60 \%$ on the shoot length of Echinochloa colonum in 2011.Concentrations 0.6 $\mathrm{gm} / \mathrm{ml}$, exhibited the highest inhibitory effect on the shoot growth of Echinochloa colonum.(89.07 and $89.83 \%$, in 2010 and 2011 respectively.

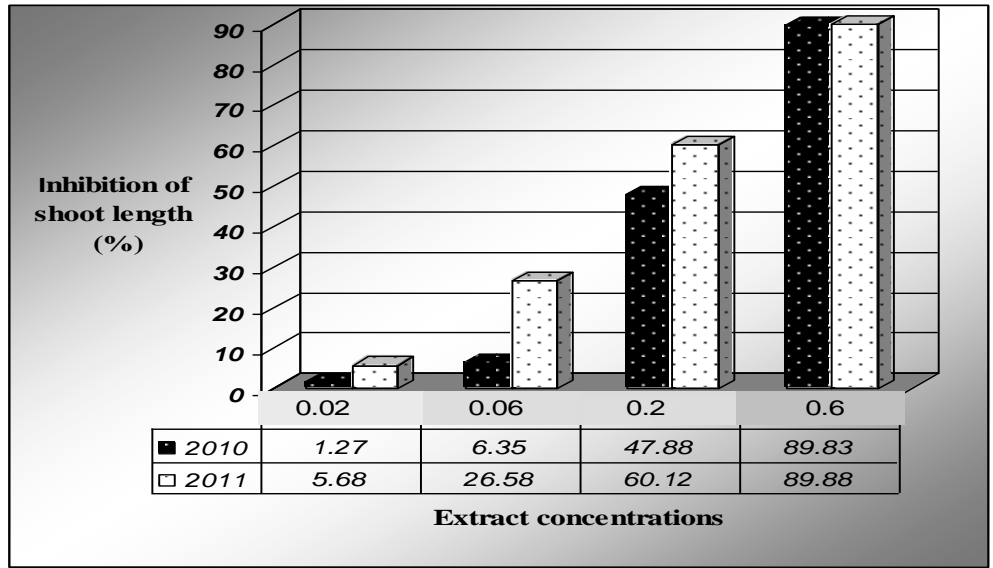

Fig. 9: Effects of methanol extracts of rice seedlings (c.v. E.Jasmine) on shoot length of Echinochloa colonum seedlings as treated by Concentrations of tested samples corresponded to the extract obtained from 0.00 (control), $0.02,0.06,0.2$ and $0.6 \mathrm{~g}$ fresh weight of rice plants $\mathrm{ml}^{-1}$. 
Data in fig (11) shows that the high growth inhibition $(60.12$ and $66.46 \%$ in 2010 and 2011 respectively ) of Echinochloa colonum roots was obtained by the extract at concentration of $0.2 \mathrm{gm} / \mathrm{ml}$, followed by the extract at concentration of $0.6 \mathrm{gm} / \mathrm{ml}$ which exhibited the highest growth inhibitory activity (89.88 and $91.01 \%$ in 2010 and 2011 respectively).
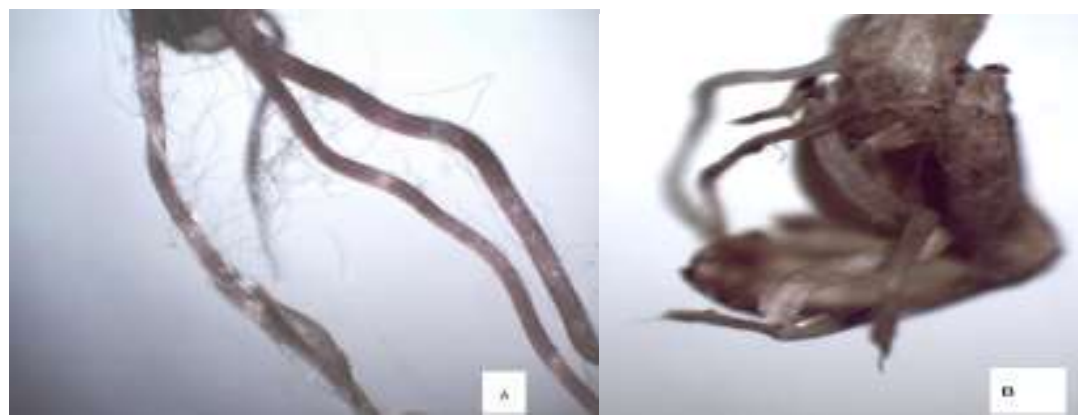

Fig. 10: Photomicrographs of Echinochloa colonum roots treated with methanol extract of rice seedlings (c.v. E.Jasmine) resulted from the concentration of 0.00 (control), and $0.6 \mathrm{gm}$ fresh weight of rice plants $/ \mathrm{ml}$.

A: 0.00 (control) B: treated with methanol extract of rice seedlings (c.v. E.Jasmine) at $0.6 \mathrm{gm}$ fresh weight of rice plants $/ \mathrm{ml}$

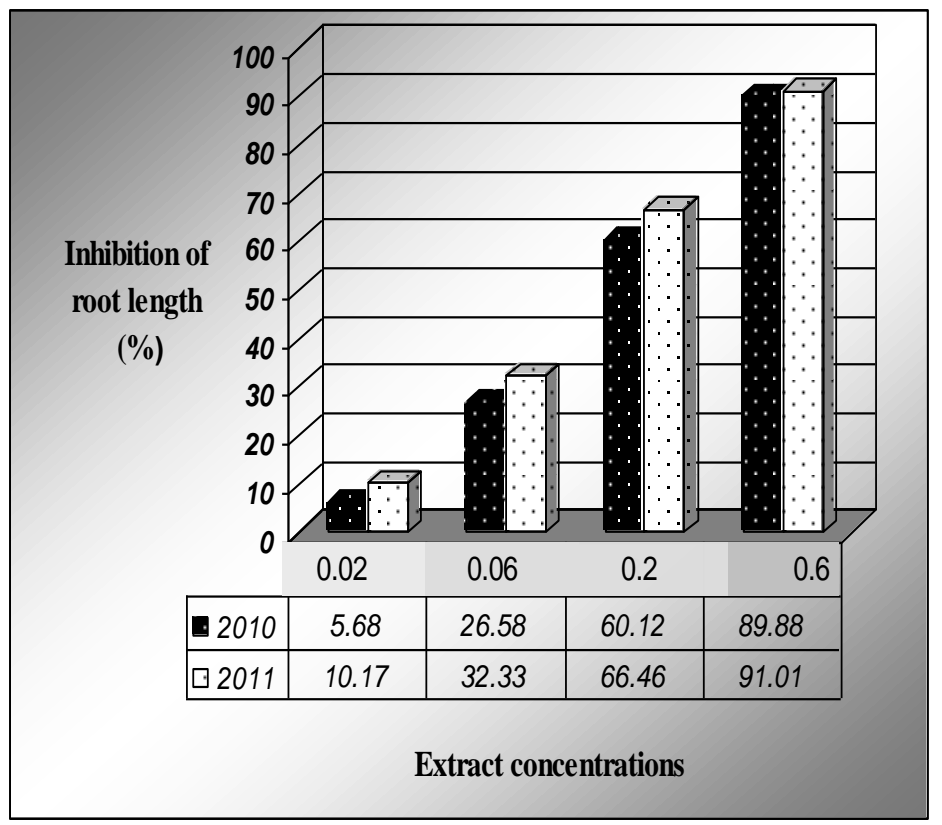

Fig. 11 : Effects of methanol extracts of rice seedlings (c.v. E.Jasmine) on root length of Echinochloa colonum seedlings as treated by Concentrations of tested samples corresponded to the extract obtained from 0.00 (control), $0.02,0.06,0.2$ and $0.6 \mathrm{~g}$ fresh weight of rice plants $\mathrm{ml}^{-1}$. 
Ashry, M.A. et al.

The results showed that the effects of methanol extract of rice cultivar (E.Jasmine) against the shoot and root growth of Echinochloa crus-galli and Echinochloa colonum, revealed that the sensitivity of roots of both weeds against the rice extract was greater than that of shoots (Fig. 11). These results are in agreement with the studies of Stachon and Zimdahl (1980). They reported that the extracts of allelopathic plants had more inhibitory effect on root growth than on hypocotyls growth. It might be due to the fact that roots are the first to absorb the allelochemicals or autotoxic-compounds from the environment. In addition, the permeability of allelochemicals to root tissue was reported to be greater than that to shoot tissue (Nishida et al. 2005). From the findings of the present study, it was observed that although hypocotyls and the root growth of target plant was less sensitive by the extract of rice cultivar at lower concentration $(0.02 \mathrm{gm} / \mathrm{ml})$, root growth was more sensitive by the extract of rice cultivar (E.Jasmine) at the higher concentration $(0.6 \mathrm{gm} / \mathrm{ml})$. The present experiment suggested that the methanol extract of rice cultivar (E.Jasmine) might possess allelopathic potential and might contain growth inhibitory substances, because methanol extract of rice seedlings have significant growth inhibitory effects on the shoot and root length of the target plant seedlings. Allelopathic substances present in rice plants, under favorable conditions, are released into the environment and likely act synergistically to affect the growth of neighboring plants Weston and Duke, (2003). However, additional studies are essential to evaluate the implications of these results to other weeds under greenhouse and field conditions. Identification of growth inhibitory compounds in the rice extracts would be necessary to properly evaluate their allelopathic potential.

\section{Anatomical differences between Echinochloa crus- galli and Echinochloa colonum as affected by methanol extract of rice seedlings (E.Jasmine) application:}

The anatomical structure changes of the tested two rice weeds (Echinochloa crus- galli and Echinochloa colonum) treated with methanol extract of rice seedlings (E.Jasmine) at $0.6 \mathrm{gm} / \mathrm{ml}$ were investigated compared with untreated plants. Reduction in root cross section and central metaxylem vessels diameters were noticed in E. crus-galli and E. colonum treated with methanol extract of rice seedlings (E. Jasmine) compared with untreated plants. Moreover, a cortex cell seems to be smaller in treated rice weeds than in untreated rice weeds. These effects may be attributed to losses in tissue water content, which reduce turgor pressure in the cell, thereby inhibiting enlargement and division of cells causing a reduction in plant growth. Similar alterations in other species have been documented (Horst, 1995; Barceló and Poschenrieder, 2002; Gunsé et al., 2003). A reduced length was appreciated in the meristematic and elongation zones of barley root (Kochian, 1995), the root changes that were accompanied by disorganization of the microtubule cytoskeleton were induced by protein kinases and phosphatases inhibitors, suggesting the effects of $\mathrm{Al}$ on mechanisms of the regulation of cell growth polarity (Horst, 1995). Cell elongation and the direction of cell expansion are linked processes of functional importance in plant development (Sugimoto et al., 2000). 


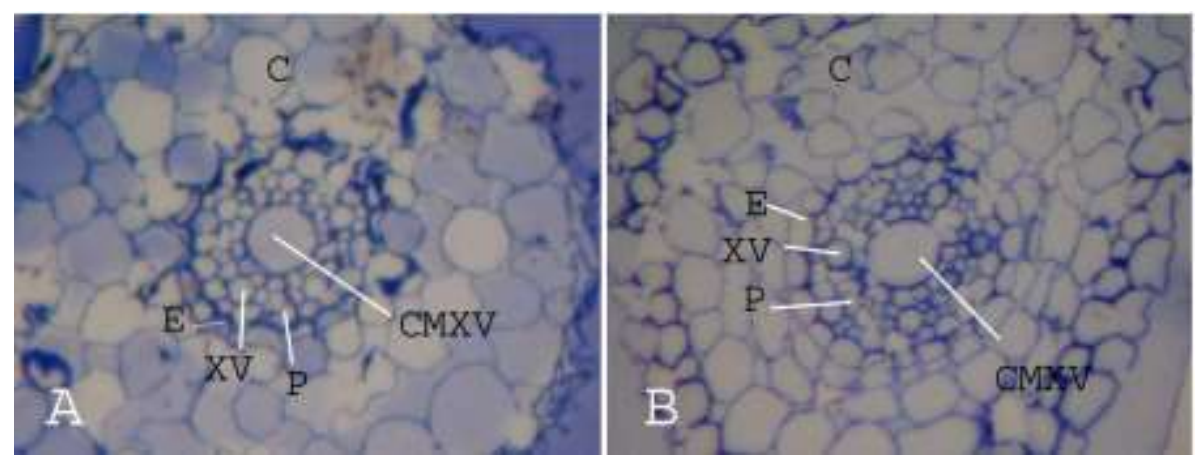

Fig. (12): Cross sections through the roots of Echinochloa crus-galli, (A) control, (B) Echinochloa crus-galli treated with methanol extract of rice seedlings (E. Jasmine).at concentration $(0.6 \mathrm{gm}$ $/ \mathrm{ml})$, C: cortex, E: endodermis, P: Pericycle, XV: xylem vessels, CMXV: central metaxylem vessel , $(X=400)$.
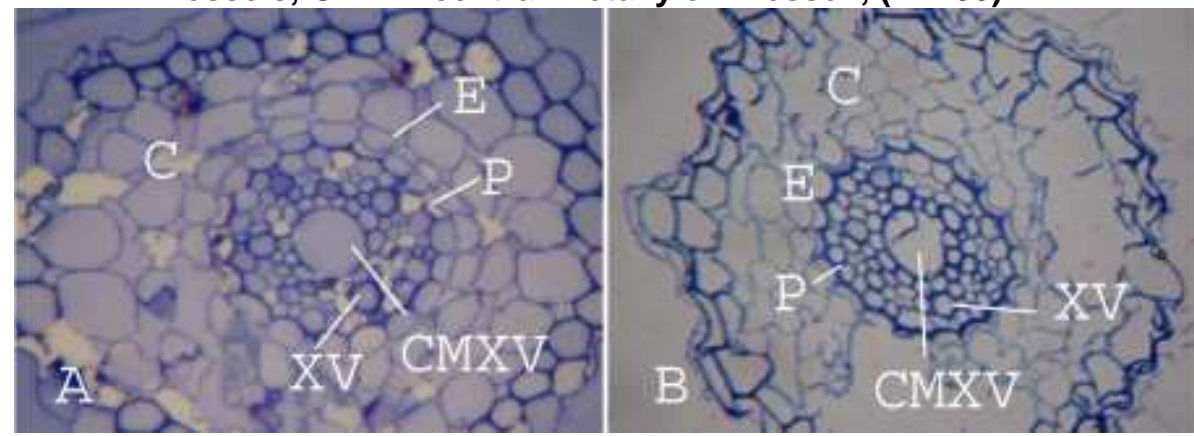

Fig. (13): Cross sections through the roots of Echinochloa colonum, (A) control, (B) Echinochloa colonum treated with methanol extract of rice seedlings (E. Jasmine).at Concentration (0.6 gm $/ \mathrm{ml}), \mathrm{C}$ : cortex, E: endodermis, P: Pericycle, XV: xylem vessels , CMXV: central metaxylem vessel $(X=400)$.

In conclusion, our data suggest that, reduction in germination \% and growth and anatomical parameters of the tested rice weeds (Echinochloa crus-galli and Echinochloa colona ) treated with methanol extract of rice cultivar (E. Jasmine). Rice cultivar Egyptian Jasmine methanol extract may be a source of natural herbicide (Bioherbicide) as a natural way towards rice weed management.

\section{REFERENCES}

Bacilio J. M., F. S. Aguilar, Z. E. Ventura, C. E. Perez, S. Bouquelet and E. Zenteno (2003) Chemical characterization of root exudates from rice (Oryza satiVa) and their effects on the chemotactic response of endophytic bacteria. PI Soil 249:271-277.

Bais HP, Vepechedu R, Gilroy S, Callaway RM, Vivanco JM.(2003) Allelopathy and exotic plant invasion: From molecules and genes to species interactions. Science; 301:1377-80. 
Barceló, J. and Poschenrieder, C.( 2002). Fast root growth responses, root exudates, and internal detoxification as clues to the mechanisms of aluminium toxicity and resistance: a review. Environm. Experim. Bot. 48: 75-92.

Bogatek, R. and A. Gniazdowska (2007). ROS and Phytohormones in PlantPlant Allelopathic Interaction. Plant Signaling \& Behavior 2:4, 317-318;

Charudattan, R. (2001). Biological control of weeds by means of plant pathogens, significance for integrated weed management in modern agroecology. Biol. Control 46:229-260.

Chung IM, K. H. Kim, J. K. Ahn, S. C. Chun and C. S. Kim (2002) Screening of allelochemicals on barnyardgrass and identification of potentially allelopathic compounds from rice variety hull extracts. Crop Pro 21: 913-920.

Chung, I. M. ; Kim, K. H. ; Ahn, J. K. and Ju, H. J. (1997). Allelopathic potential of rice varieties on Echinochloa crus-galli. Korean J. Weed Sci. 17, 52-58.

Dilday, R. ;Lin, J. and Yan, W. (1994). Identification of allelopathy in the USDA-ARS rice germplasm collection. Australian Journal of Experimental Agriculture. 34(7) 907 - 910.

Dilday, R.H. ;Yan, W.G. ;Moldenhauer, K. and Gravois, K. A. (1998) Allelopathic activity in rice for controlling major aquatic weeds. In: Olofsdotter M (ed) Allelopathy in Rice. International Rice Research Institute, Manila. pp 7-26.

Duke, S. (2007).Weeding with allelochemicals and allelopathy-a commentary. Pest Manag Sci. 63:307.

Duke, S. O. ;Dayan, F. E. ;Romagni, J. G. and Rimando, A. M. (2000). Natural products as sources of herbicides, current status and future trends. Weed Res.40:99-111.

Einhellig, F. (1996). Interactions involving allelopathy in cropping systems. Agron. J. 88:886-893.

Fujii, Y. (1992).The allelopathic e.ect of some rice varieties. In: Proc. Int. Symp. on Biological Control. and Integrated Management of Paddy and Aquatic Weeds in Asia, Tsukuba, 1-6.

Gealy, D. ;Wailes, E. ;Esterninos, L. and Chavez, R. (2003). Rice cultivar differences in suppression of barnyardgrass (Echinochloa crus-galli) and economics of reduced propanil rates. Weed Sci. 51:601-609.

Gunsé, B. ;Garzón, T. and Barceló, J. (2003). Study of aluminum toxicity by means of vital staining profiles in four cultivars of Phaseolus vulgaris $\mathrm{L}$. Plant Physiol. Urban \& Fischer Verlaghttp://www.urbanfischer.de/journals/jpp.

Hassan S. M. ;Aidy, I.R. ;Bastawisi, A. O. and Draz, A. E. (1998). Weed management using allelopathic rice varieties in Egypt. In: Olofsdotter $M$ (ed) Allelopathy in Rice. International Rice Research Institute, Manila, Philippies. pp 27-37.

Heidarzade, A., H. Pirdashti and M. Esmaeili (2010). Quantification of allelopathic substances and inhibitory potential in root exudates of rice (Oryza sativa) varieties on Barnyardgrass (Echinochloa crus-galli L.). Plant Omics Journal, 3(6):204-209 
Horst, W. (1995). The role of the apoplast in aluminum toxicity and resistance of higher plants: a review. Z. Pflanzenernaehr. Bodenkd. 158:419-428

Inderjit, W. (2006) Experimental complexities in evaluating the allelopathic activities in laboratory bioassays. Soil Bio Biochem 38: 256-262.

Kato-Noguchi H and T. Ino (2005) Possible involvement of momilactone B in rice allelopathy. J Plant Physi 162: 718-721.

Kawaguchi, S. Yoneyama,K. Yokota,T. Takeuchi,Y. Ogasawara, M. and Konnai, M. (1997). E.ects of aqueous extract of rice plants (Oryza sativa L.) on seed germination and radicle elongation of Monochoria vaginalis var. plantaginea. Plant Growth Regul. 23.183-189.

Kochian, L.V. (1995). Cellular mechanisms of aluminium toxicity and resistance in plants. Annu. Rev. Plant Physiol. Mol. Biol. 46: 237-270.

Kong, C. Hu, F. Wang, P. and Wu, J. (2008). Effect of allelopathic rice varieties combined with cultural management options on paddy field weeds. Pest Manag. Sci . 64: 276-282 .

Kucera, B., M. A. Cohn and G. Leubner-Metzger (2005). Plant hormone interactions during seed dormancy release and germination. Seed Sci Res 2005; 15:281- 307.

Leather, G. R. and Einhellig, F. A. (1986). Bioassays in the study of allelopathy. In: A. R. Putnam, and C. S. Tang (eds). The Science of Allelopathy. John Wiley and Sons, New York. 133-145.

Liebman, M. and Davis, A. (2000). Integration of soil, crop and weed management in low-external-input farming systems. Weed Res. 40:2747.

Mattice J,T. Lavy, B. Skulman and R. H. Dilday (1998) Searching for allelochemicals in rice that control ducksalad, In: Olofsdotter, M. (ed). Allelopathy in Rice. International Rice Research Institute, Manila p 81 98

Minorsky, P. (2002). Allelopathy and grain crop production. Plant Physiol. 130:1745-1746.

Navarez, D. and Olofsdotter, M. (1996). Relay seeding technique for screening allelopathic rice (Oryza sativa). Proc. 2nd Int. Weed Control Congr., Copenhagen, 1285-1290.

Nishida, N. Tamotsu, S. Nagata, N. Saito, C. and Sakai, A. (2005). Allelopathic Effects of Volatile Monoterpenoids Produced by Salvia leucophylla: Inhibition of Cell Pro life ration and DNA Synthesis in the Root Apical Meristem of Brassica campestris Seedlings. Journal of Chemical Ecology, 31: 1187-1203.

Olofsdotter. M. Jensen, L. B. and Courtois, B. (2002). Improving crop competitive ability using allelopathy - an example from rice. Plant Breeding. 121: 1-9.

Olofsdotter, M. Navarez, D. and Moody, K.(1995). Allelopathic potential in rice (Oryza sativa L.) germplasm. Ann. Appl. Biol. 127. 543-560.

Olofsdotter, M. Navarez, D. and Rebulanan, M. (1997). Rice allelopathy where are we and how far can we get? Brighton Crop Protect. Conf. Weeds.1. 99-104.

Putnam, A.(1988). Allelochemicals from plants as herbicides. Weed Technol. 2:510-518. 
Ashry, M.A. et al.

Shibayama, H. (2001).Weeds and weed management in rice production in Japan. Weed Biol. Manag. 1:53-60.

Stachon, W. J. and Zimdahl, R. L.(1980). Allelopathic activity of Canada thistle Cirsium arvense in Colorado. Weed Sci. 28:83-86.

Sugimoto, K. Williamson, R.E. and Wasteneys, G.O.(2000). New techniques enable comparative analysis of microtubule orientation, wall texture, and growth rate in intact roots of Arabidopsis. Plant Physiol. 124: 14931506.

Weir T, S. W. Park and J. M. Vivianco (2004). Biochemical and physiological mechanisms mediated by allelochemicals. Curr Opin Plant Biol 7:4729.

Weston, L. A. (1996). Utilization of allelopathy for weed management in agroecosystems. Agron. J. 88:860-866.

Weston, L . A. and Duke, S. O. (2003). Weed and crop allelopathy. Plant sciences. 22(3\&4):367-389.

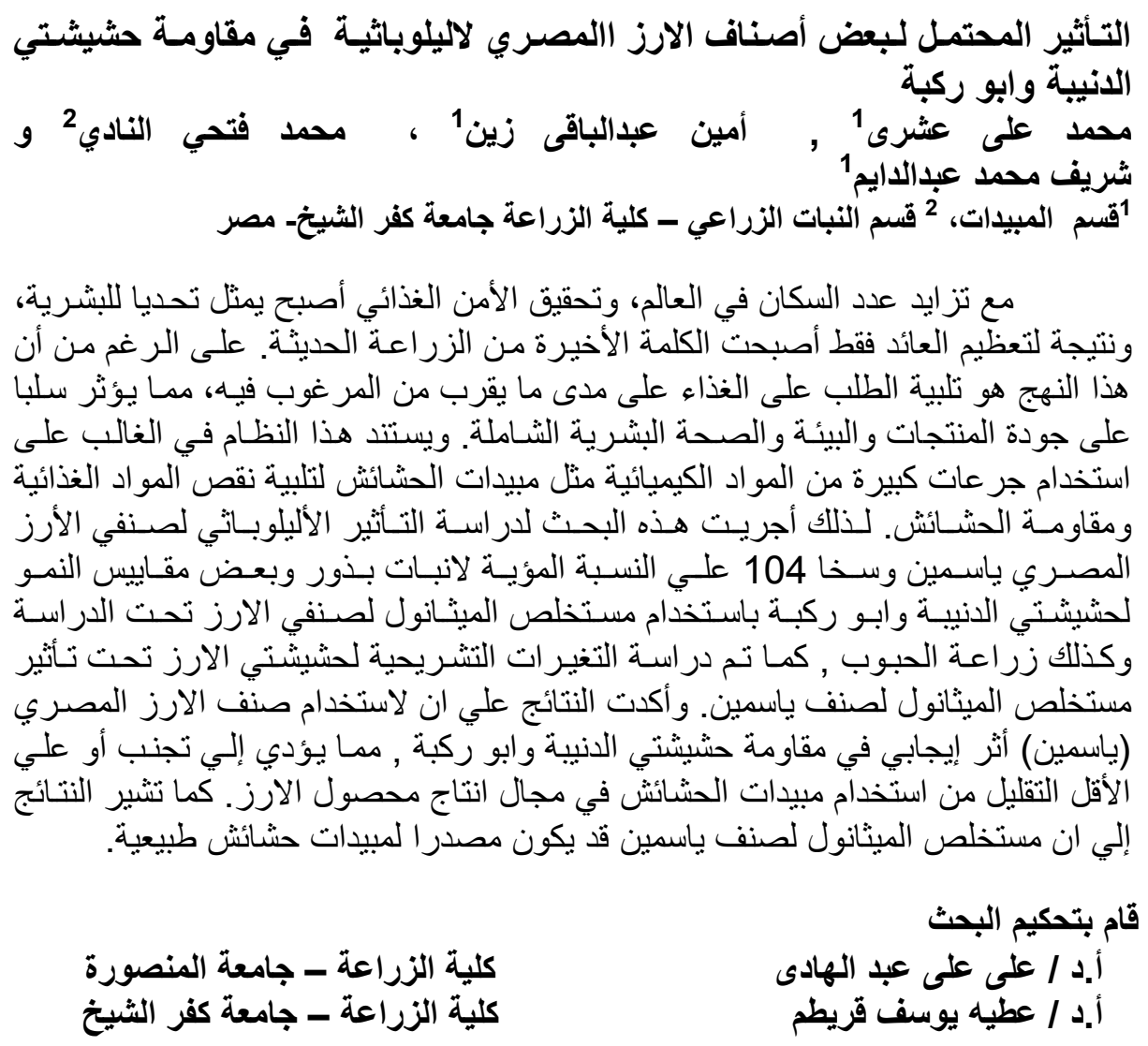

